\title{
Conclusions: Still Risking Implementation Gaps
}

\author{
Sabrina Cavatorto and Antonio La Spina
}

\begin{abstract}
Continuity and differentiation elements in the administrative reform cycles are considered from the perspective of implementation, and its gaps. The reformist seasons of the last 25 years mostly shared the same principles, goals and weaknesses in their implementation phases. The vicious cycle of administrative reforms has not been defused: the widespread disagreement in the policy community against further waves of comprehensive reform is an indicator of a persistent low degree of practical implementation, and rather of the prevalence of contradictory effects with respect to reforming principles and goals, like the performance evaluation introduced by statute in 2009. Creeping resistance within administrations is a constant presence, apparently unaffected by several waves of normative innovation. Notwithstanding the recent call for "concreteness" of the Five-Star Movement and League "government of change", we find that the lack of empirical, in-depth organizational analysis gives the real measure of current complexity to be dealt with.
\end{abstract}

Keywords Implementation • Managerial autonomy • Politicization • Top civil servants $\bullet$ Independent authorities

(C) The Author(s) 2020 


\subsection{Exogenous Pressures Without Convergence}

Public policies - including administrative reforms-are more and more influenced by several supra-national, cross-national and global factors which are not in control of nation states. Some international organizations (such as the Organisation for Economic Cooperation and Development (OECD), the United Nations, the World Bank and the International Monetary Fund) can suggest or-under certain conditions-request certain reform paths. When among such institutions there is consensus about some contents of the reforms that are deemed necessary (as it was apparently the case on new public management (NPM) in certain historical phases), the influence that they can exert is supposed to become stronger (La Spina 2020).

Private bodies, such as rating agencies or institutional investors, can also have an impact on domestic choices (although they are more interested in budgetary and economic policies). Other ratings-like those of the Doing Business reports published by the World Bank-are more focused upon the attractiveness and investment climate exhibited by each country, which are of course tied, among other things, to the functioning of public administrations (PAs). International economic competition is a driver for change in regulation and public administration.

Domestic economies are dependent on the contingencies of global economic cycles. This is especially evident during downturns, which can offer unusual opportunities for certain reform packages concerned with structural adjustment. As we have seen in this book, such packages can cover administrative reforms.

International epistemic communities, composed of scholars, think tanks and experts of a given field, can also be rather influential (Haas 1992; La Spina 2020). Policy options which are considered successful tend to be imitated abroad. Ideas are relevant. "Perhaps the single most important source of ideas and policy innovation are practices that prevail elsewhere. The fact that a policy has worked — or at least is perceived to have workedsomewhere can be a powerful reason to copy it" (Rodrik 2014: 204).

Certain public bodies (such as independent regulators) participate in international networks and therefore feel a pressure to conform to what is estimated normal or dutiful by their foreign peers. The same can happen with the directors of some ministerial departments.

The most important exogenous influence, which often amounts to a constraint, is exerted by the EU. This happens through legislation, budgetary discipline, cohesion funds, action programmes and 
recommendations. For instance, the directives on public procurement were intended to have a direct impact on a crucial activity of public bureaucracies. The imposition of austerity as a response to the risks of default after the 2008 recession affected the size of public employment, salaries, performance pay, recruitment and collective contracts (Di Mascio et al. 2013; Di Mascio and Natalini 2014). Cohesion policy addresses administrative modernization and capacity-building through the supply of dedicated financial resources (European Commission 2017a, b). Some EU action programmes, like the one on administrative burdens measurement and reduction, were also focused on administrative culture and innovation (European Commission 2012).

We might go on at length. What was sketched above is enough to show that also with regard to administrative reform certain salient sources, factors and decision-making powers are more and more exogenous to nation states. Furthermore, it could be argued that, generally speaking, such external pressures push towards policy convergence, defined by Knill (2005: 768; see also Holzinger and Knill 2005; Drezner 2005) as "any increase in the similarity between one or more characteristics of a certain policy (...) across a given set of political jurisdictions (...) over a period of time. Policy convergence thus describes the end result of a process of policy change". We can also suppose that the more some domestic policy is divergent from the exogenous accepted standard, the more forceful will be the pressure aimed at obtaining convergence.

Overall, when the emphasis is on the need to recover reliability and budgetary discipline, performance improvement could understandably become less central (Kickert et al. 2013; Di Mascio et al. 2013). It must also be said that reforms inspired by public management in certain countries were less successful than expected (De Vries and Nemec 2013; Pollitt and Bouckaert 2017; Van Dooren and Hoffmann 2018). Internal resistances (also by professionals, see Bezes et al. 2012) as well as domestic societal features can play a role in retarding or distorting convergence (Jordan 2005; Lenschow et al. 2005), which cannot be complete and immediate. Nevertheless, convergent policies in some of the most important sectors are increasing, in connection to the diminishing sovereignty of nation states.

All the exogenous influences just mentioned-ranging from the OECD's recommendations to the contents of the Merida convention, and of course to what was asked by the EU-played a role in the Italian case. However, some of the developments that we have hitherto highlighted 
also tell a different story, as we showed in the various chapters of this book. With regard to anti-corruption, for example, convergence was actually absent until 2012. With regard to public procurement, EU legislation notwithstanding, the Merloni law was first suspended and then superseded in 2006 by a code of public contracts which was much less convergent. The new code adopted in 2016 was not welcomed by everybody. Then it has been partially revised and is undergoing other substantial changes. As far as public managers and performance evaluation are concerned, we have witnessed a gap between the official provisions of several legislative decrees and the real functioning of flesh-and-blood public bureaucracies. The "end result" of all these efforts is still far away from convergence. Even when it was possible to use cohesion funds which had been earmarked for administrative modernization, they were sometimes granted on the basis of formal, extrinsic compliance (the official adoption of certain norms), without checking whether real administrative behaviours had been actually modified. This "taught" concerned bureaucrats a perverse lesson: that certain requirements could have been circumvented, that symbolic innovation was sufficient and that it was possible to get away with it, or even being rewarded for it (La Spina 2007).

We can conclude that, at least with regard to administrative reforms, and more specifically to performance improvement, Italian policymaking in the last three decades has exhibited an official endorsement of their need, but did not managed to guarantee the actual fulfilment of convergence. Why? This is the question we continue to ask.

It is precisely to the implementation failures that this conclusive chapter is devoted. The vicious cycle of administrative reforms in Italy is also explained with a focus on the most recent developments from the 18th legislature (started on 23 March 2018). The commitment of the Five-Star Movement and the League "government of change" to achieve the "concreteness" of existing regulation regarding the PA governance, instead of changing it in a comprehensive way, has been hence especially taken into consideration. The coalition agreed on an independent Prime Minister, although close to the Five-Star: the private law professor Giuseppe Conte, almost unknown to the public. Yet, the same commitment to the "concreteness" of the implementation, in continuity with previous waves of comprehensive administrative reforms, was confirmed by the Five-StarDemocratic Party (PD) coalition, which unpredictably succeeded the sudden collapse of the Conte I government (August 2019), letting Prime Minister Conte survive in his role (Conte II). 


\subsection{Overcoming the Lack of Implementation With (What Kind of?) "Concreteness"}

With regard to the PA, the "government of change" (1 June 2018-4 September 2019) intended first of all to intervene on the failure of implementing existing laws. In Italy some administrations implemented innovations, but others did not. This is why the modernization rate of the Italian PA as been judged low, because of the lack of homogeneity of implemented reforms, as well as the heterogeneity of the administrations themselves. The latter makes regulatory efficiency a complex problem per se.

According to the new minister for public administration of the Conte I cabinet, Giulia Bongiorno (a lawyer, centre-right MP from 2006 to 2013, elected in 2018 to the Senate with the Lega, but as an independent), no new "maxi" reform was needed, just the application of the "reasonable" and "shared" laws that already exist in Italy: "I want to be an implementing legislator"; "some good things have been done, and I don't reject them because they were made by the left; instead, where I see gaps, I have to intervene". ${ }^{2}$ Hence the issue of putting norms into practice more clearly entered the policy agenda: since "practical implementation walks on the legs", the M5S-League government's "concreteness" law ${ }^{3}$ has addressed the problem of PA's different speeds in the way it established a team of specialized subjects (Unit of "concreteness", i.e. Nucleo) for the improvement of PA organizational efficiency. On that account, the Nucleo is now aimed at supporting the diffusion of best practices from "top-level" administrations-"that in fact there are"- to those in difficulty (Ibidem). Moreover, the Nucleo is expected to act as a "tutor" who intervenes where needed to recommend organizational remedies. Consequently, the Nucleo's added value should first be on the side of organizational action: "The Nucleo of concreteness has the sole purpose of helping, collaborating,

\footnotetext{
${ }^{1}$ Parliamentary hearing on the programmatic lines of the Minister Giulia Bongiorno (Joint Chambers 26/9/2018).

${ }^{2}$ Prosecution of the parliamentary hearing of the Minister Giulia Bongiorno (Joint Chambers 13/2/2019).

${ }^{3}$ Senate Bill 920 was approved in first reading by both the Chambers, then discussed in second reading in the Senate for the final approval by the assembly on 12 June 2019 (the date was postponed due to the European elections) (http://www.senato.it/leg/18/BGT/ Schede/Ddliterl/50887.htm). The law was linked to the 2019 public finance manouvre and entered into force in July (law 56/2019 "Interventions for the concreteness of public administration").
} 
indicating corrective actions (...) It does not want to interfere, it wants to help" (Ibidem).

However, the "concrete" actions for the efficiency of public administrations have been not identified on a case-by-case basis. Rather, they are expected to be described in a three-year action plan (i.e. the "plan of the concrete actions"), prepared, centrally, by the Department of Public Administration. ${ }^{4}$ Anyhow, the information available has not allowed to clarify what the specific contents of this plan will be and how materially the activation of the Nucleo will be realized. In addition, according to the current legislation, the same policy objectives must be already included in the "Performance Plan", which is to be drawn up by each PA (see Chap. 5), obligation to which still not all PAs fulfill. ${ }^{5}$ Besides, hardly same level of operational detail could be reached by a plan only elaborated at the central level. The Nucleo's profile of organizational support risks then to be sacrificed within a top-down regime, which includes disciplinary-although presented as "not punitive" - actions. As a matter of fact, in order to overcome administrative inertia and contrast organizational inaction, in the minister's design "a managerial responsibility has to be triggered". Afterwards, "it is right that those who do not comply (with the Nucleo's recommendations), they will suffer the consequences", namely being registered in a "black list" of defaulting administrations (Ibidem).

At present, it is also worth mentioning that the compliance of the administrative action is (ex post) supervised by the "Inspectorate for the public function", acting together with the Financial Guard (Guardia di Finanza), the military police force under the authority of the Ministry of Economy and Finance (Fig. 6.1 ${ }^{6}$ ). The Nucleo should instead verify (in itinere, and consequently recommending corrective operational measures) the practical implementation of the provisions on organization and functioning, especially to promote transparency and digitalization, as well as on human resource management, in order to increase the efficiency of public administrations. But uncertainty about the boundaries of the two

\footnotetext{
${ }^{4}$ Law 56/2019, Art. 1, Par. 2.

${ }^{5}$ The monitoring by the Department of Public Administration calculated that, as of $1 / 3 / 2019$, only $26 \%$ of administrations $(\mathrm{N}=80)$ fully complied with the deadline of 31 January, publishing the "Performance Plan 2019-2021" (https://performance.gov.it/system/files/Monitoraggio/Monitoraggio\%20periodico\%20\%28marzo\%202019\%29.pdf).

${ }^{6}$ Since 2017, the Inspectorate also implements that part of the Madia law devoted to strengthen the sanctions against low productivity and absenteeism of public-sector employees, the "idlers" or furbetti del cartellino (legislative decree 116/2016).
} 


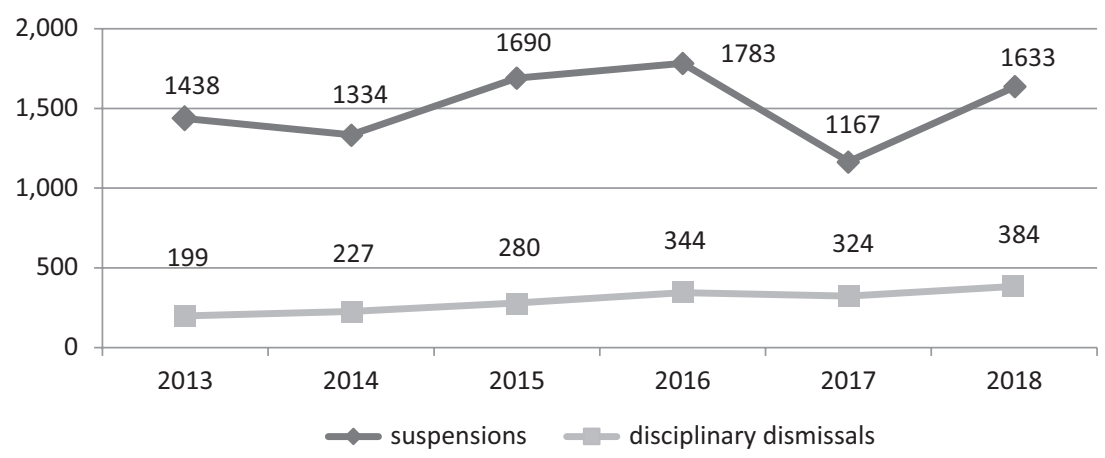

Fig. 6.1 Compliance checks by the Inspectorate for the public function and "severe" sanctions. (Source: Own elaboration from http://www.funzionepubblica.gov.it/strumenti-e-controlli/controlli-ispettorato/documentazione)

bodies' scope of intervention, due to risk of overlaps, was object of widespread criticism during the parliamentary examination, even from the institutional and stakeholders' hearings. ${ }^{7}$ Strong opposition was also expressed by the regions and the autonomous provinces in the Unified Conference, because of the perceived excessive interference in the organization of regional offices. ${ }^{8}$ On the contrary, accompanying organizational actions have been widely welcome. ${ }^{9}$

Anyhow, on the Nucleo's functions, the Minister Bongiorno spoke of "so much confusion in interpretation, at times perhaps wanted", and insisted that it differs from the Inspectorate, with which it is albeit expected to cooperate. To "transfer" the organizational models, "we need someone surely doing the job" (Idibem). Yet, after all, nothing has been specified as for the expertise of the Nucleo's components. Not surprisingly, for the many critical issues raised, the new PA minister of the Conte II government, the 36-year old Fabiana Dadone (Five-Star), has announced that she does not exclude to put the profile of the Nucleo under re-consideration.

\footnotetext{
${ }^{7}$ See for instance the Court of Auditors' opinion (Senate 26/11/2018).

${ }^{8}$ Extraordinary Meeting 31/10/2018.

${ }^{9}$ Among the most recent participatory contributions, the "ForumPA 2018 White Paper on PA innovation" recommends a "legislative moratorium" in favour of forms of organizational change sustained by the digital transformation (https://librobianco-innovazione-pa2018-final.readthedocs.io/it/latest/).
} 
The fight against absenteeism likewise has become a confirmed political priority. At any rate, the connection between the "presence in service" of public employees and the effective improvement in the quality of administrative action is unlikely to be obvious. Therefore, even though it was ascertained that the progressive introduction of biometric surveys and the video surveillance of accesses does not violate-but just under certain conditions ${ }^{10}$ - the privacy policy, as the public discourse about the introduction of "fingerprints" in the public employment had also complained, the new rule does not cope with the issue of the effectiveness of PA organizational structure: Without appropriate attributions of competences and a systematic performance evaluation by the top managers, that actually are critical issues, public employees should be "fixed" in their place to do what? On grounds of which motivations? ${ }^{11}$

Measures have been withal put in place so as to accelerate "targeted recruitments" in the following areas: digitalization, organization and administrative simplification, quality of services, structural funds management and investments, public contracts, audit and inspecting activity, public accounting and financial management. "If we make targeted, intelligent assumptions, it means restarting the PA, those offices that are sometimes deprived of personnel, as in the very crucial field of justice" (Ibidem). Accordingly, the generational turnover is confirmed, ${ }^{12}$ as the Renzi government already planned (see Chap. 3), but within the new budgetary constraints established by the M5S-League executive, which imposed another block on recruitments (albeit defined as "technical", i.e. just for accounting purposes by reason of EU fiscal coordination) for the duration of almost the whole year 2019 (Table 6.1), aside from the following sectors: law enforcement agencies, the fire corps, school and health. ${ }^{13}$ Simplified procedures to speed up recruitments (Fig. 6.2) have been also mentioned, making the public concorsi more frequent (yearly), thus abolishing the rankings of eligible candidates, to be called in the longer run. As

\footnotetext{
${ }^{10}$ As made clear by the Italian Data Protection Authority (Garante per la protezione dei dati personali), heard in the Senate (26-27/11/2018).

${ }^{11}$ The same minister admits that if "we let them in, we have to make them work; yet, in the meantime, we have not cut resources, but invested" (Parliamentary hearing, Joint Chambers $13 / 2 / 2019)$.

${ }^{12}$ The costs should cover $100 \%$ of retirements.

${ }^{13}$ In the same areas, the $100 \%$ turn over's quota is not applied; sector regulations already in force prevail.
} 
Table 6.1 Turn over quotas in central PA (\% of expenditure equal to that relating to personnel who left the previous year)

\begin{tabular}{rrlll}
\hline 2014 & $20 \%$ & Decree-law & & \\
2015 & $40 \%$ & $90 / 2014$ (Art. & & \\
2016 & $60 \%$ & 3, Par. 1) & $25 \%$ & Stability Law 2016 (law 208/2015, Art. 1, Par. \\
2017 & $80 \%$ & $25 \%$ & 228 ); for the year 2019, Budget law 2019 (law \\
2018 & $100 \%$ & $25 \%$ & $145 / 2018$, Art. 1, Par. 399) blocked recruitments \\
2019 & & $100 \%$ & until 15 November \\
\hline
\end{tabular}

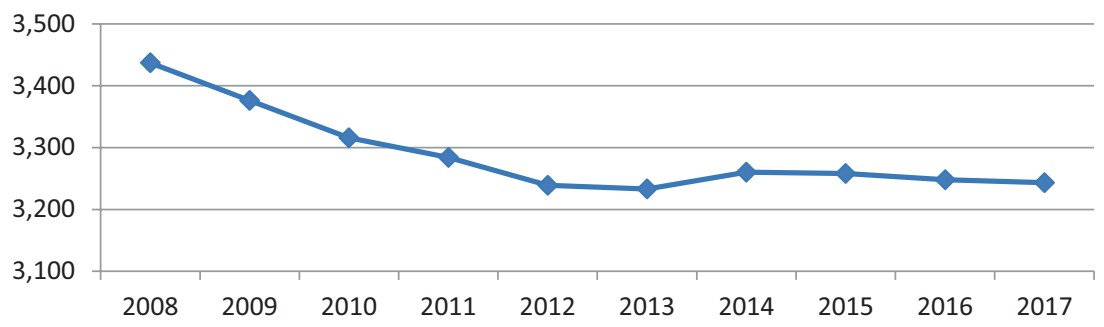

Fig. 6.2 Total staff employed by public administrations per year (thousands of units). The Annual Account shows the data on the consistency and costs of PA personnel and constitutes the official source of information for decisions regarding public employment. (Source: General State Annual Account 2017)

already established by the Madia reform, ${ }^{14}$ the concorsi must be centrally managed by the Department for PA, which is asked-now by the law, not "solely" by ministerial guidelines, which actually are said to be well functioning ${ }^{15}$ - to provide a recruitment website (Portale del reclutamento), with candidates' individual electronic pages (Fascicolo del candidato). Reasonably this rule, transparency oriented, has been relaunched by the new Minister Dadone.

Within certain limits, but again in great continuity with the existing norms (i.e. law 114/2014), mobility has been encouraged, both territorially and between public institutions, that operate at the international level

${ }^{14}$ In April 2018, minister Madia approved the "Guidelines on recruitment procedures", published on the official journal-Gazzetta Ufficiale - on 12/6/2018. The minister's directive executed the legislative decree $75 / 2017$, which modified the 2001 consolidate text on public employment (see Chaps. 3 and 5).

${ }^{15}$ As shown by a certain number of hearings during the parliamentary debate. 
too, or between the public and private sectors. A similar web portal was devoted in 2015 to the same purpose ${ }^{16}$; however, it seems no more updated now. On the same point, we can conclude that if so many websites are launched but not systematically implemented, they for sure will increase a sense of fragmentation instead of transparency.

In terms of implementation, one of the most significant effort, confirmed over time since the Bassanini's reform cycle in the late 1990s, has been simplification. ${ }^{17}$ By definition, as an institutionalized policy goal, simplification could — and should — be a never-ending story, featuring systemicwide challenges, now more intensively reframed through the digitalization imperative. "Administrative simplification is an obscure activity (...), which will never be a topic for parliamentary debates, (...) or press coverage; yet, it must absorb the greatest energy nowadays, from central to local administrations" (Ibidem). This component of Madia's inputs, in continuity with the past, was explicitly shared by Minister Bongiorno and, after her, also agreed by Minister Dadone (see also Table 6.2).

At the same time, the Conte I executive continued on the path of legislative simplification passing "urgent provisions on support and simplification for businesses and the PA" through the decree-law $135 / 2018$, then converted into law $12 / 2019$, which was highly contested by the oppositions due to its prominent omnibus profile, for example even including a norm about the extension of the Alitalia loan, strictly linked to the budget law approved shortly before. Besides, always in connection with the 2019 budget law, on 28 February 2019, the Council of Ministers approved further ten delegating bills providing simplifications and codifications in a vast number of policy fields (public procurement, civil code and military order comprised). The scope of this legislative delegation was very ambitious and described a medium-long term perspective. Being the parliamentary exam at the very beginning at the time of our analysis, it was too early to make assessments or forecasts.

Anyhow, it deserved to be pointed up that nearly all hearings during the parliamentary discussions relating to administrative reforms in the 18th Legislature, along with the public discourse that emerged from most of the speeches in the 2019 ForumPA - that is, the Italian annual convention

\footnotetext{
${ }^{16}$ https://www.mobilita.gov.it/home.php.

${ }^{17}$ The monitoring of the "Agenda for simplification 2015-2017" estimated that $98 \%$ of actions were realized (as reported by the Economic and Financial Document, DEF, 2018).

See also http://www.funzionepubblica.gov.it/semplificazione and http://www.italiasemplice.gov.it/.
} 
Table 6.2 Designing PA change through EU structural resources (2014-2020)

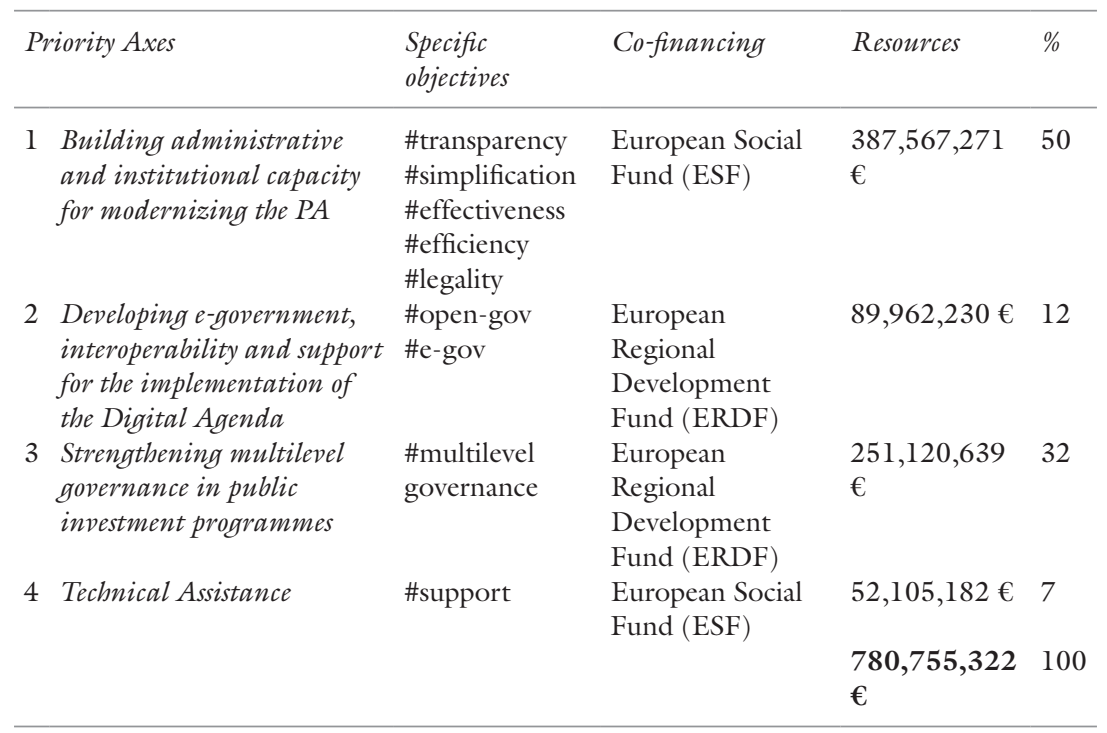

As known, the projects are co-financed: $75 \%$ by the $\mathrm{EU}$ and $25 \%$ by the member state

Source: http://www.pongovernancel420.gov.it/en/programme/action-strategy/documents/

devoted, since 1990 , to the topic of innovation in the public sector ${ }^{18}$ expressed scepticism towards any new legislative proposal that ignores a targeted and in-depth analysis of public organizations, as the Madia law even established, again without adequate implementation so far.

In her impetus towards concreteness, Minister Bongiorno extensively recognized that "the legislator's limit is the effectiveness of what is done inside (emphasis added) the offices: this is the public manager's job" ${ }^{19}$ On that account, "the reform of reforms" still consists of innovating the top management profile and effectively working to redesign the public employees competencies and skills. "I want passionate managers, (...) making others grow, (...) soliciting, helping, rewarding, and sharing objectives" (Ibidem). Not a different attitude was expressed by the Minister Dadone in

${ }^{18}$ In 2019, events were about "PA as a creator of public value" (https://forumpa2019. eventifpa.it/it/2019/02/13/forum-pa-2019-creare-valore-pubblico/). Since a while, the ForumPA narrative has been articulated along five keywords: digitalization, rejuvenation, simplification, communication and merit. The context of action is that of sustainability.

${ }^{19}$ Parliamentary hearing, Joint Chambers 13/2/2019. 
the beginning of her mandate. She stressed - and soon realized - a more consultation-oriented approach aimed at "re-starting from the people, and the work organization". ${ }^{20}$

Under the necessary umbrella of digital transformation, ${ }^{21}$ the search for convergent policy solutions in that no longer postponable direction makes us understand the attention that has been recently devoted, although in the "legalist" Italian PA, to behavioural-oriented approaches. ${ }^{22}$ Actually, the effects of such a vogue require to be concretely monitored in the medium term, as the empirical science of administration would properly suggest.

\subsection{The Crux of the Top Management Reform, When Looking at the Future}

Owing to the long politicization's tradition of Italian PA, human resources management was the area where the gap between reform design and implementation has been larger (Ongaro and Valotti 2008).

${ }^{20}$ Parliamentary hearing on the programmatic lines of the Minister Fabiana Dadone (Chamber of Deputies 11/12/2019). The Conte II cabinet has inaugurated the first governmental Italian digital platform devoted to public consultation and participation processes (https://partecipa.govit/).

${ }^{21}$ Pillars of this policy strategy have been granted by structural funds in the context of the Operative Programme (OP) on "Governance and Institutional Capacity" for the 2014-2020 period (http://www.pongovernancel420.gov.it/en/): the Department of PA is responsible for the Digital Agenda and modernization processes, such as simplification or performance evaluation (for instance, the project RiformAttiva supports the implementation of innovative actions at the territorial level; Cloudify NoiPA is focused on the digital transformation of human resources management at all level of government; the Delivery Unit is devoted to simplification and red tapes' cuts); the Ministry of Justice is especially delegated to the enforcement of civil justice, as also recommended by the European Council (see Chap. 2).

${ }^{22}$ Under the Gentiloni government, a working group was formed at the presidency of the Council of Ministers with the purpose of developing a research plan to apply behavioural sciences in the management of administrative processes (Secretary General decree of 13 September 2017). To confirm the perspective, the National School of Administration (SNA) began offering courses on modern "nudging" techniques to public civil servants and managers, and also funded university masters on that topic. Furthermore, a course on "Cognitive Sciences and Behavioral PA" has been launched as an action under the OP Governance 2014-2020 in the field of cohesion policy to promote "a better interaction between administrations and the beneficiaries of the interventions, with the final recipients, and among public employees involved in the management of the operational tools" (http://www.pongovernancel420.gov.it/it/rafforzare-le-politiche-di-coesione-attraverso-il-behavioural-insights/). 
A central pillar of the Madia reform was that on the top management, whose proposal was however rejected by a sentence of the Constitutional Court in 2016 (see Chaps. 3 and 5), then not reformulated by the Gentiloni government. Why is this component of the PA reform so difficult to achieve?

It is well known that large part of Italian top executives did not agree on the new perspective, ${ }^{23}$ for corporate, clearly defensive ${ }^{24}$ reasons that the current government would seem to welcome more openly. ${ }^{25}$ This means that bureaucratic politics consistently matters when reforms are at issue.

For the time being, ten years after its introduction (legislative decree $150 / 2009$, see Chap. 5), the performance evaluation system has been widely considered "the" administrative reforms' failure. It is diffusely believed that "the reform of reforms" has to be restarted from there.

Again, the then Minister Bongiorno in front of the Parliament: "The top management reform is one of those things that had no results so far. The effort now is to create evaluators who are third parties. (...) Everyone will say that in some way we want to create a sort of control over the top management; $(\ldots)$ but the reform is not a punishment! (...) if the objectives are homemade, they do not make any sense; at the same time, if evaluations are mild, they cannot really help the PA; (...) if I had an excellent PA, then I would understand all these 100\% (i.e. full score)" (Ibidem). But this is not the situation.

The problem of performance is thus first of all organizational, before than individual, having produced direct wage effects, hence having been

\footnotetext{
${ }^{23} \mathrm{~A}$ joint document raising doubts about the draft of the Madia law's implementing decree was-among others-presented in October 2016 to the Committee for Constitutional Affairs of the Chamber of Deputies by two associations of public managers, together with the Association Nuova Etica Pubblica. Particularly critical also a document published in July 2017 by Nuova Etica Pubblica, which complains about the Madia reform as a policy failure (https://www.eticapa.it/eticapa/documento-ufficiale-di-nuova-etica-pubblica-sul-fallimentodelle-riforme-amministrative/).

${ }^{24}$ On "defensive bureaucracy", see Battini and Decarolis (2019). An interesting research panel was carried out by FPA (May 2017) "Burocrazia difensiva. Come ne usciamo?” (https:// www.forumpa.it/riforma-pa/burocrazia-difensiva-come-ne-usciamo-una-ricerca-di-fpa/).

${ }^{25}$ As it can be seen from the hearings realized at the beginning of the exam of the Senate Bill 1122 "Delegation to the Government for PA improvement" (April-May 2019): the professional associations expressed themselves in a quite auspicious way (http://www.senato.it/leg/18/BGT/Schede/Ddliter/51407.htm\#).
} 
mostly - and ineffectively_characterized as self-referential. ${ }^{26}$ On the contrary, a "competent" organization could encourage a clearer distinction between political direction and high-level managerial (i.e. technical) activity, although the two are in the field intricately linked.

Indeed, the historian of public administration Melis (2015: 284-285) suggests that the privatization of employment relationships brings with it a direct and personal connection between managers and their political principals (see also Battini and Cimino 2007; Antonelli and La Spina 2010). This tendency can be either accepted as unavoidable or curtailed (like the Italian Constitutional Court did in the past). One of the objectives of new public management (NPM) was that of "reasserting political control over the administration" (Van de Walle 2018: 2). Therefore, in principle politicization of top managers is not incompatible with a rather high degree of managerial autonomy. Pollitt and Bouckaert (2017: 58-60) nevertheless argue that in some countries such as Canada, New Zealand, and the United Kingdom (which used to be among the most well-known champions of NPM), the careers of "mandarins" in ministerial departments most of the times are neatly separated and relatively insulated from politics.

When explaining variation in European public sectors, Van de Walle (2018) found that in Italy, as well as in Spain and Portugal, perceived managerial autonomy is the lowest, but he also confirmed that "(the lack of) managerial autonomy and politicization-i.e. regular political interference-are different concepts" (Ivi: 13). ${ }^{27}$ Indeed, he found clear findings related to structural factors, such as organization's type and size, and the hierarchical position of the respondent, even in cases where the interaction frequency with the responsible minister is high.

Additionally, already Ongaro and Valotti (2008) added confidence to the fact that behavioural factors may influence differences in the implementation of public management reforms, although in turn influenced by

\footnotetext{
${ }^{26}$ Among others, a critical assessment of the current situation by Enrico Deidda Gagliardo (Member of the Performance Technical Committee at the Department of PA) taking part in the ForumPA 2019, together with Marco De Giorgi (Director General, Office for Performance Evaluation, Department of PA) (https://forumpa2019.eventifpa.it/it/ event-details /?id=8521).

${ }^{27}$ The data set contains information on top managers in central governments (see the COCOPS project already mentioned in Chap. 1: http://www.cocops.eu/). "Managerial autonomy" refers to autonomy that managers perceive to have in making decisions about issues like budget allocations, hiring and firing, and contracting out (Ivi: 3).
} 
the administrative tradition and the politico-administrative context dominating the country.

According to Melis (2015: 291-292), administrative reforms in Italy were often and mostly seen in terms of "personnel policy, systematically ignoring $(\ldots)$ organization, service productivity, relationships with citizens". Moreover, in his view the choices made were frequently instrumental "to clientelistic, electoral and anyway contingent objectives": there are too much public managers, insufficiently shielded against political interferences, and de facto unaccountable with regard to objectives, results and merit. As we have seen in the previous chapter, all these topics were actually tackled several times, at least since 1993. However, it cannot be denied that the real functioning of Italian public bureaucracies still exhibits the critical aspects mentioned by Melis. Particularism, inefficiency and resistance to change tend to coalesce, obstructing the path of performance improvement.

As we have already shown, Republican Italy lacked for decades an anticorruption policy, which was launched and then strengthened in parallel with the creation and institutionalization of an independent authority. Even when the given status quo is resistant and blocked, it is possible, under certain conditions, to imagine and actually use an exogenous lever for change. This does not necessarily mean that the changes produced will always be appropriate, or long-lasting, as suggested by the recent decisions concerning the code of public contracts and the relevant ANAC's competences.

The planning of anti-corruption has many elements in common with the planning and evaluation of performance. Nevertheless, as we have seen, performance evaluation was taken away from the authority for public administration. Unlike what later became the ANAC, the CIVIT had been initially established without powers. However, the same had happened in the past also in the cases of other independent bodies. Over time they gradually grew stronger and enlarged their range of action. Had the CIVIT lived enough time, perhaps it could have gone through a similar path. For instance, it could have tried to homogenize the way similar public organizations design their performance plans, implement them and evaluate the ensuing results. Such an approach would, among other things, relieve some of the burdens of performance planning and evaluation, so that the justified complaints of many administrations would be met. As we have seen, an attempt at homogenization was made through the creation of some central commissions for managerial appointments, but it was defeated. 
The independent bodies for performance evaluation (OIVs) were expected to be a crucial lever for performance improvement. However, the way their members are chosen as well as the nature of the principals to which they owe their appointment are not necessarily conducive to independence and expertise. The relevant provisions remained mostly ineffective "because the introduction of performance evaluation tools is mostly left to spontaneous decisions of political echelons, without appropriate supervision, monitoring, and sanctioning in case of failed implementation" (Merloni 2018: 92). The OIVs have to confront politicians, public managers, civil servants, endowed with resources that range from funds to legal powers, or political influence. If they were chosen by an independent authority and were directly answerable to it, this could enhance their level of both independence and technical competence, by shielding them vis-àvis some particularistic pressures stemming from the administrations that they are supposed to evaluate. It might even be discussed whether a new independent authority could also administer sactions and exert powers of direct intervention, like the AVSPP proposed in 2006.

Independent bodies as a policy tool have advantages and disadvantages. In some political systems, they enjoy a certain legitimization by public opinion and political elites. The opposite can be true for some other systems, at least in certain periods of their political history (La Spina and Majone 2000). Understandably, having to address the extremely resilient Italian bureaucracies, an authority for public administration would need a robust and continued popular and political support, with regard to both its tasks and its independency. This used to be unlikely (although not impossible) in the past. On the one hand, it is very difficult to forecast whether such a support will be found in the future. On the other, the Italian administrative system (like many others) was seriously shaken by the Covid-19 emergency. This has had devastating consequences, but at the same time has increased and sharpened citizens' expectations towards the public sector. Therefore, a favourable occasion has emerged for wideranging and impactful reforms, that could interrupt the long chain of mistakes made in the past. 


\section{REFERENCES}

Antonelli, V., \& La Spina, A. (Eds.). (2010). I dirigenti pubblici e $i$ nodi del cambiamento. Roma: Luiss University Press.

Battini, S., \& Cimino, B. (2007). La dirigenza pubblica italiana tra privatizzazione e politicizzazione. Rivistra trimestrale di diritto pubblico, 4, 1001-1034.

Battini, S., \& Decarolis, F. (2019). L'amministrazione si difende. Rivista trimestrale di diritto pubblico, 1, 293-320.

Bezes, P., Demazière, D., Le Bianic, T., Paradeise, C., Normand, R., Benamouzig, D., Pierru, F., \& Evetts, J. (2012). New Public Management and Professionals in the Public Sector. What New Patterns Beyond Opposition? Sociologie du travail, 54, el-e 52.

De Vries, M., \& Nemec, J. (2013). Public Sector Reform: an Overview of Recent Literature and Research on NPM and Alternative Paths. International Journal of Public Sector Management, 26(1), 4-16.

Di Mascio, F., \& Natalini, A. (2014). Austerity and Public Administration: Italy Between Modernization and Spending Cuts. American Behavioral Scientist, 58(12), 1634-1656.

Di Mascio, F., Natalini, A., \& Stolfi, F. (2013). The Ghost of Crises Past: Analyzing Reform Sequences to Understand Italy's Response to the Global Crisis. Public Administration, 91(1), 17-31.

Drezner, D. W. (2005). Globalization, Harmonization, and Competition: The Different Pathways to Policy Convergence. Journal of European Public Policy, 12(5), 841-859.

European Commission. (2012). Action Programme for Reducing Administrative Burdens in the EU-Final Report. Strasbourg.

European Commission. (2017a). Quality of Public Administration-A Toolbox for Practicioners. Theme 9: Public Administration Reform-Making Positive Change Happen. Luxembourg: Publication Office of the European Union.

European Commission. (2017b). Quality of Public Administration: A Toolbox for Practicioners. Some Considerations on Managing Thematic Objective 11. Luxembourg: Publication Office of the European Union.

Holzinger, K., \& Knill, C. (2005). Causes and Conditions of Cross-National Policy Convergence. Journal of European Public Policy, 12(5), 775-796.

Jordan, A. (2005). Policy Convergence: A Passing Fad or a New Integrating Focus in European Union Studies? Journal of European Public Policy, 12(5), 944-953.

Kickert, K., Randma-Liiv, T., \& Savi, R. (2013). Fiscal Consolidation in Europe: A Comparative Analysis. COCOPS Working Paper 7.2. Retrieved February, 2019, from http://www.cocops.eu.

Knill, C. (2005). Introduction: Cross-National Policy Convergence: Concepts, Approaches and Explanatory Factors. Journal of European Public Policy, $12(5), 764-774$. 
La Spina, A. (2007). Politiche per il Mezzogiorno e riforma amministrativa. Rivista Italiana di Politiche Pubbliche, 3, 5-39.

La Spina, A. (2020). Politiche pubbliche. Analisi e valutazione. Bologna: Mulino. La Spina, A., \& Majone, G. (2000). Lo Stato regolatore. Bologna: Mulino.

Lenschow, A., Liefferink, D., \& Veenman, S. (2005). When the Birds Sing. A Framework for Analysing Domestic Factors Behind Policy Convergence. Journal of European Public Policy, 12(5), 797-816.

Melis, G. (2015). Fare lo Stato per fare gli italiani. Bologna: Mulino.

Merloni, F. (2018). Costituzione repubblicana, riforme amministrative e riforme del sistema amministrativo. Diritto pubblico, 1, 81-120.

Ongaro, E., \& Valotti, G. (2008). Public Management Reform in Italy: Explaining the Implementation Gap. International Journal of Public Sector Management, 21(2), 174-204.

Pollitt, C., \& Bouckaert, G. (2017). Public Management Reform. A Comparative Analysis - Into the Age of Austerity (4th ed.). Oxford: Oxford University Press.

Peter M. Haas, (1992) Introduction: Epistemic Communities and International Policy Coordination. International Organization, 46 (1): 1-35.

Rodrik, D. (2014). When Ideas Trump Interests: Preferences, Worldviews, and Policy Innovations. Journal of Economic Perspectives, 28(1), 189-208.

Van de Walle, S. (2018). Explaining Variation In Perceived Managerial Autonomy and Direct Politicization in European Public Sectors. International Review of Administrative Sciences, 85(4), 1-18.

Van Dooren, W., \& Hoffmann, C. (2018). Performance Management in Europe: An Idea Whose Time Has Come and Gone? In E. Ongaro \& S. Van Thiel (Eds.), The Palgrave Handbook of Public Administration and Management in Europe (pp. 207-225). London: Palgrave. 